\title{
Front Matter: Volume 8198
}

, "Front Matter: Volume 8198," Proc. SPIE 8198, 2011 International 'Conference on Optical Instruments and Technology: Optoelectronic Devices and Integration, 819801 (13 December 2011); doi: 10.1117/12.922966

SDIE Event: International Conference on Optical Instruments and Technology (OIT2011), 2011, Beijing, Beijing, China 


\title{
PROCEEDINGS OF SPIE
}

\section{International Conference on Optical Instruments and Technology \\ Optoelectronic Devices and Integration}

\author{
Xuping Zhang \\ P. K. Alex Wai \\ Hai Ming \\ Editors
}

6-9 November 2011

Beijing, China

Sponsored by

CIS - China Instrument and Control Society

COS - The Chinese Optical Society

SPIE

Cooperating Organizations

Opto-Electronic - Mechanic Technology and System Integration Chapter, CIS (China) • Beijing Institute of Technology (China) - University of Shanghai for Science and Technology (China) Capital Normal University (China) • Optical Instrument Chapter, CIS (China) • Committee on Optoelectronic Technology, COS (China) • Beijing Hamamatsu Photon Techniques Inc. (China) Tianjin University (China) • Zhejiang University (China) • Tsinghua University (China) • Chongqing University (China) • Nanjing University (China) • Instrument Society of America (China) • Institute of Measurement and Control (United Kingdom) $\bullet$ Hong Kong Institution of Engineers (China) The Society of Measurement and Control (Japan)

Published by

SPIE

Volume 8198 
The papers included in this volume were part of the technical conference cited on the cover and title page. Papers were selected and subject to review by the editors and conference program committee. Some conference presentations may not be available for publication. The papers published in these proceedings reflect the work and thoughts of the authors and are published herein as submitted. The publisher is not responsible for the validity of the information or for any outcomes resulting from reliance thereon.

Please use the following format to cite material from this book:

Author(s), "Title of Paper," in 2011 International Conference on Optical Instruments and Technology: Optoelectronic Devices and Integration, edited by Xuping Zhang, P. K. Alex Wai, Hai Ming, Proceedings of SPIE Vol. 8198 (SPIE, Bellingham, WA, 2011) Article CID Number.

ISSN 0277-786X

ISBN 9780819488398

Published by

SPIE

P.O. Box 10, Bellingham, Washington 98227-0010 USA

Telephone +1 3606763290 (Pacific Time) · Fax +1 3606471445

SPIE.org

Copyright (C) 2011, Society of Photo-Optical Instrumentation Engineers

Copying of material in this book for internal or personal use, or for the internal or personal use of specific clients, beyond the fair use provisions granted by the U.S. Copyright Law is authorized by SPIE subject to payment of copying fees. The Transactional Reporting Service base fee for this volume is $\$ 18.00$ per article (or portion thereof), which should be paid directly to the Copyright Clearance Center (CCC), 222 Rosewood Drive, Danvers, MA 01923. Payment may also be made electronically through CCC Online at copyright.com. Other copying for republication, resale, advertising or promotion, or any form of systematic or multiple reproduction of any material in this book is prohibited except with permission in writing from the publisher. The CCC fee code is 0277-786X/11/ \$18.00.

Printed in the United States of America.

Publication of record for individual papers is online in the SPIE Digital Library.

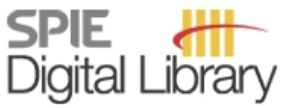

SPIEDigitalLibrary.org

Paper Numbering: Proceedings of SPIE follow an e-First publication model, with papers published first online and then in print and on CD-ROM. Papers are published as they are submitted and meet publication criteria. A unique, consistent, permanent citation identifier (CID) number is assigned to each article at the time of the first publication. Utilization of CIDs allows articles to be fully citable as soon as they are published online, and connects the same identifier to all online, print, and electronic versions of the publication. SPIE uses a six-digit CID article numbering system in which:

- The first four digits correspond to the SPIE volume number.

- The last two digits indicate publication order within the volume using a Base 36 numbering system employing both numerals and letters. These two-number sets start with $00,01,02,03,04$, $05,06,07,08,09,0 A, 0 B \ldots 0 Z$, followed by 10-1Z, 20-2Z, etc.

The CID number appears on each page of the manuscript. The complete citation is used on the first page, and an abbreviated version on subsequent pages. Numbers in the index correspond to the last two digits of the six-digit CID number. 


\title{
Contents
}

\author{
vii Symposium Committee \\ ix Conference Committee \\ xi Introduction
}

\section{SESSION 1 PHOTONIC CRYSTAL FIBER AND ITS APPLICATION}

819802 Silicon-nanomembrane-based photonic crystal nanostructures for chip-integrated open sensor systems (Invited Paper) [8198-52]

S. Chakravarty, Omega Optics, Inc. (United States); W.-C. Lai, Y. Zou, C. Lin, The Univ. of Texas at Austin (United States); X. Wang, Omega Optics, Inc. (United States); R. T. Chen, Omega Optics, Inc. (United States) and The Univ. of Texas at Austin (United States)

819803 A novel notch filter based on block copolymer photonic crystal [8198-01]

S. Hara, T. Yamanaka, T. Hirohata, M. Niigaki, Hamamatsu Photonics K. K. (Japan)

$819804 \quad$ A modified vector mode solution of step index fiber [8198-14]

F. Guo, L. Li, H. Zheng, Y. Wang, J. Ke, T. Dai, Fujian Normal Univ. (China)

\section{SESSION 2 FIBER AND FIBER SENSOR I}

819806 Impact of the pattern layout on the performance of photonic crystal Fano broadband reflectors (Invited Paper) [8198-02]

Z. Chen, Z. Qiang, X. XU, J. Jiang, Fujian Normal Univ. (China); X. Chen, Minjiang Univ. (China); Y. Qiu, Fujian Normal Univ. (China)

819807 First-principles calculations of band-gap properties of zinc-blende $\mathrm{B}_{\mathrm{x}} \mathrm{Ga}_{1-\mathrm{x}} \mathrm{N}$ and $\mathbf{B}_{\mathrm{x}} \mathbf{G a}_{1-\mathrm{x}} \mathbf{N}_{\mathbf{y}} \mathrm{As}_{1-\mathrm{y}}$ alloys [8198-55]

K.-H. LV, Q. Wang, Y.-C. Yan, X. Guo, Y.-Q. Huang, X.-M. Ren, Beijing Univ. of Posts and Telecommunications (China)

819808 Application of frequency spectrum analysis in measuring multi-vibrations by using POTDR [8198-49]

X. Wang, X. Zhang, F. Wang, M. Chen, C. Li, Nanjing Univ. (China)

\section{SESSION 3 APPLICATION OF FIBER LASER I}

8198 OA Numerical analysis of an ytterbium-doped few-mode fiber laser [8198-15]

Z. Lin, A. Wang, L. XU, B. Sun, C. GU, H. Ming, Univ. of Science and Technology of China (China)

8198 OB Switchable triple-wavelength erbium-doped fiber laser based on two series connected Lyot-Sagnac filter [8198-17]

G. Qiao, Z. Cao, R. Wang, X. Ji, B. Gao, X. Zhang, B. Yu, Anhui Univ. (China) 
$81980 \mathrm{C}$ Characteristics of diffraction beam of $\mathrm{TE}_{01}$ mode of step index fiber [8198-44]

F. Guo, L. Li, H. Zheng, Y. Wang, T. Dai, J. Ke, Fujian Normal Univ. (China)

\section{SESSION 4 APPLICATION OF FIBER LASER II}

8198 OE A switchable dual-wavelength erbium-doped fiber laser based on a two-taper MachZehnder interferometer filter [8198-40]

R. Wang, Z. Cao, X. Ji, G. Qiao, X. Zhang, B. Yu, Anhui Univ. (China)

8198 OF Design of novel tunable resonant cavity enhanced photodetector (RCE-PD) [8198-56]

B. Zhao, Y. Huang, X. Fan, Y. Zhou, X. Duan, X. Ren, Beijing Univ. of Posts and

Telecommunications (China)

\section{SESSION 5 FIBER AND FIBER SENSOR II}

8198 OG All-fiber similariton ultrashort pulse laser systems at erbium-doped wavelengthband (Invited Paper) [8198-18]

L. Zhan, J. Peng, Z. Gu, S. Luo, Q. Shen, Shanghai Jiao Tong Univ. (China)

$8198 \mathrm{OH} \quad$ High speed data encryption and decryption using stimulated Brillouin scattering effect in optical fiber (Invited Paper) [8198-12]

L. Yi, T. Zhang, W. Hu, Shanghai Jiao Tong Univ. (China)

8198 ol High-speed physical random number generation using a chaotic semiconductor laser [8198-11]

J. Z. Zhang, J. F. Wang, Y. C. Wang, Taiyuan Univ. of Science and Technology (China)

8198 0J Bimetallic chips for SMX sensing in a surface plasmon resonance instrument [8198-13]

Y. Chen, Y. Lu, D. Zhang, P. Wang, H. Ming, Univ. of Science and Technology of China (China)

$81980 \mathrm{OK}$ The influence of graded $\ln _{\mathbf{x}} \mathrm{Ga}_{1-\mathrm{x}} \mathrm{As}$ on strain distribution and the band gap in the $\operatorname{InAs} / \mathrm{GaAs}$ quantum dots [8198-57]

J. Wang, Q. Wang, X. Guo, X. Ren, X. Zhang, Y. Huang, Beijing Univ. of Posts and

Telecommunications (China)

POSTER SESSION

$8198 \mathrm{OL}$ Generation of space-variant polarized beams by use of segmented subwavelength metallic gratings [8198-07]

Z. Zhou, Beijing Information Science and Technology Univ. (China) and Tsinghua Univ.

(China); Q. Tan, Tsinghua Univ. (China)

$81980 \mathrm{M}$ Highly polarized $\mathrm{Yb}$-doped fiber laser based on a polarization-maintaining fiber Sagnac loop mirror and its power amplification [8198-09]

L. Zhang, Shanghai Institute of Optics and Fine Mechanics (China) and Graduate Univ. of the Chinese Academy of Sciences (China); J. H. Wang, Shanghai Institute of Optics and Fine Mechanics (China) and National Univ. of Defense Technology (China); X. J. Gu,

Ryerson Univ. (Canada); Y. Feng, Shanghai Institute of Optics and Fine Mechanics (China) 
8198 ON Fusion splicing special large-mode-area single-mode optical fibers and conventional single-mode fibers [8198-19]

Z. Shen, J. Ren, H. Yang, National Univ. of Defense Technology (China)

819800 Numerical simulation on spectral compression of frequency-shifting femtosecond pulses in photonic crystal fiber [8198-25]

S. N. Li, H. P. Li, Q. M. Wang, J. K. Liao, X. G. Tang, R. G. Lu, Y. Liu, Y. Z. Liu, Univ. of Electronic Science and Technology of China (China)

8198 OP The interference and integration of a fiber electro-optic intensity modulator [8198-29] W. Lei, G. He, Z. Liu, Harbin Engineering Univ. (China)

$81980 Q \quad$ Illumination uniformity of a spherical target directly driven by fiber lasers [8198-30] T. Xu, C. Gu, L. Xu, A. Wang, H. Ming, Univ. of Science and Technology of China (China)

8198 OR Highly efficient TEMoo mode LD-pumping 1063nm Nd:GdVO laser with short cavity [8198-35] X. Liu, S. Fu, X. Ge, C. Yuan, Shandong Univ. of Technology (China)

8198 OS The effect of stimulated Brillouin scattering effects on noise figure in fiber amplifiers [8198-38] A. Wei, L. Xu, A. Wang, H. Ming, Univ. of Science and Technology of China (China)

8198 0T The characteristics of dynamic gratings in ultra-narrow linewidth erbium-doped fiber ring lasers [8198-39]

P. Xu, Z. Hu, Y. Hu, M. Ma, L. Ma, National Univ. of Defense Technology (China)

$81980 \mathrm{U} \quad$ Nonlinear propagation of stacking chirped pulses in single-mode fiber [8198-47] J. Liu, A. Wang, L. Xu, H. Ming, Univ. of Science and Technology of China (China)

8198 OV Colloidal photonic crystals assembled on the cladding of optical fibers [8198-51] W. H. Guo, Nanjing Normal Univ. (China) and Changshu Institute of Technology (China); M. Wang, W. Xia, L. H. Dai, Nanjing Normal Univ. (China)

8198 OW Polarization splitter based on a porous silicon waveguide [8198-54]

Y. Liu, Xi'an Jiao Tong Univ. (China) and Xinjiang Univ. (China); Z. Jia, Xinjiang Univ. (China)

$81980 \mathrm{X}$ Optimization of the high repetition rate all-fiber two-stage ytterbium-doped fiber amplifier [8198-91]

J. Yun, C. Gao, S. Zhu, C. Sun, Xi'an Institute of Optics and Precision Mechanics (China); L. Dong, Xi'an Institute of Optics and Precision Mechanics (China) and Graduate School of the Chinese Academy of Sciences (China)

Author Index 
Downloaded From: https://www.spiedigitallibrary.org/conference-proceedings-of-spie on 26 Apr 2023

Terms of Use: https://www.spiedigitallibrary.org/terms-of-use 


\section{Symposium Committee}

General Chairs

Songlin Zhuang, University of Shanghai for Science and Technology (China)

Brian Culshaw, University of Strathclyde (United Kingdom)

Conference Cochairs

Yuri Chugui, New Siberia Academy of Sciences (Russian Federation)

Arthur Chiou, National Yang-Ming University (Taiwan, China)

Shenghua Ye, Tianjin University (China)

Honorary Chairs

Daheng Wang, Chinese Academy of Sciences (China)

Guoguang Mu, Nankai University (China)

Bingkun Zhou, Tsinghua University (China)

Technical Program Chair

Guofan Jin, Tsinghua University (China)

Technical Program Cochairs

Jinxue Wang, SPIE

Yimo Zhang, Tianjin University (China)

Local Organizing Committee Chair

Youhua Wu, China Instrument and Control Society (China)

Local Organizing Committee Cochairs

Guoqiang Ni, Beijing Institute of Technology (China)

Daoyin Yu, Tianjin University (China)

Yulin Xi, Beijing Hamamatsu Photon Techiques Inc. (China)

General Secretary

Youhua Wu, China Instrument and Control Society (China) 
Administrative Vice General Secretary

Boyu Ding, Beijing Institute of Technology (China)

Vice General Secretaries

Yuejin Zhao, Beijing Institute of Technology (China)

Tiegen Liu, Tianjin University (China)

Qionghui Feng, University of Shanghai for Science and Technology (China)

Cunlin Zhang, Capital Normal University (China)

Local Organizing Committee

Duanyi Xu, Tsinghua University (China)

Weimin Chen, Chongqing University (China)

Hongda Chen, Institute of Semiconductors (China)

Shangzhong Jin, China Jiliang University (China)

Libo Yuan, Harbin Engineering University (China)

Chunqing Gao, Beijing Institute of Technology (China)

Shiqiao Qin, National University of Defense Technology (China)

Tian Lan, Beijing Institute of Technology (China)

Cuiling Li, Beijing Institute of Technology (China)

Liquan Dong, Beijing Institute of Technology (China) 


\title{
Conference Committee
}

\author{
Conference Chairs \\ Xuping Zhang, Nanjing University (China) \\ P. K. Alex Wai, The Hong Kong Polytechnic University (Hong Kong, \\ China) \\ Hai Ming, University of Science and Technology of China (China) \\ Program Committee \\ Xiaoyi Bao, University of Ottawa (Canada) \\ Gilberto Brambilla, University of Southampton (United Kingdom) \\ Lawrence R. Chen, McGill University (Canada) \\ Gualtiero Nunzi Conti, Istituto di Fisica Applicata Nello Carrara (Italy) \\ Xuejun Lu, University of Massachusetts Lowell (United States) \\ Gary R. Pickrell, Virginia Polytechnic Institute and State University \\ (United States) \\ Zexuan Qiang, The University of Texas at Arlington (United States) \\ Suning Tang, Crystal Research, Inc. (United States) \\ Scott S. H. Yam, Queen's University (Canada) \\ Changyuan Yu, Nantional University of Singapore (Singapore) \\ Jianguo Zhang, London South Bank University (United Kingdom) \\ Feng Song, Nankai University (China) \\ Edwin Y. B. Pun, City University of Hong Kong (Hong Kong, China)
}

\section{Session Chairs}

1 Photonic Crystal Fiber and its Application

Xuping Zhang, Nanjing University (China)

2 Fiber and Fiber Sensor I

Jianguo Zhang, London South Bank University (United Kingdom)

3 Application of Fiber Laser I

Li Zhan, Shanghai Jiao Tong University (China)

4 Application of Fiber Laser II

Ray T. Chen, The University of Texas at Austin (United States)

$5 \quad$ Fiber and Fiber Sensor II

Xueming Liu, Xi'an Institute of Optics and Precision Mechanics (China) 
Downloaded From: https://www.spiedigitallibrary.org/conference-proceedings-of-spie on 26 Apr 2023

Terms of Use: https://www.spiedigitallibrary.org/terms-of-use 


\section{Introduction}

These proceedings are from the 2011 International Conference on Optical Instrument and Technology (OIT2011), held in Beijing, China, 7-9 November 2011. The conference was the third event following the success of OIT'08 and OIT'09 and was sponsored and supported by SPIE, China Instrument and Control Society (CIS), and the Chinese Optical Society (COS).

OlT2011 was a professional conference which was combined and focused on instrument science and related technology, and involved in many technical aspects such as detection; observation; information collection, transfer and storage; communication; economization on energy; environmental protection; inspection and prevention of food security, traffic safety and mine safety; measure and control for aviation and space engineering, etc.

These proceedings, a collection of six volumes, contain the accepted oral and poster papers presented at OIT2011. It is truly a great pleasure for me that the most recent progress in optical instrumentation technology is reported in the OIT2011 proceedings. I firmly believe that the papers included in these volumes will provide reference information in the most up-to-date techniques of optical instrumentation technology.

The OIT2011 conference collected over 330 papers from different countries or regions of the world. Over 300 authors came from more than 12 countries. This conference consists of eight oral sessions (and a one-day poster session): Optical Systems and Modern Optoelectronic Instruments; Optical Device \& Integration; Optical Sensor and Applications; Opto-electronic Imaging and Processing Technology; Optoelectronic Measurement Technology and System; Solid State Lighting and Display Technologies; Holography, Speckle Pattern Interferometry and Application; Micro/Nano Manufacturing and Metrology. Published in these six volumes of the Proceedings of SPIE are close to 330 papers. The technical fields of the presented papers at the conference cover a lot of current advanced technologies. The cutting-edge technologies and applications of optical instruments are discussed. Quite a few invited papers describe exciting achievements in the fields of optical instrument technology. It is evident that the OlT2011 conference has provided an excellent platform for participants and colleagues in research and development to share the technical progress and to develop new partnerships or broaden new markets.

SPIE has given great support to organize this international conference by collaborating with us in the whole organizing process from abstract collection to the proceedings publication. COS has provided great support and assistance. 
Finally, on behalf of CIS and conference general chairs, I would like to heartily thank our supporters and committee members for all they have done for this conference. Thanks also go to all authors for their contributions, to all of the participants and friends for their interest, especially those who have traveled great distances and taken time from their busy schedules to attend the conference. Thanks also go to the staff of CIS for their support. I am also grateful to the SPIE staff for their support and collaboration in publishing these six volumes.

Songlin Zhuang

Chairman, China Instrument and Control Society (CIS) 